\title{
The Essential Oil Components of Helichrysum pallasii Flowers ${ }^{\#}$
}

\author{
Emine Yurteri ${ }^{1, a, *}$, Fatih Seyis ${ }^{1, b}$, Haydar Kuplemez ${ }^{1, c}$ \\ ${ }^{1}$ Field Crops Department, Faculty of Agriculture, Recep Tayyip Erdogan University, 53100 Rize, Turkey \\ *Corresponding author

\begin{tabular}{|c|c|}
\hline R T I C L E I N & \\
\hline $\begin{array}{l}\text { \#This study was presented as an online } \\
\text { presentation at the } 2^{\text {nd }} \text { International } \\
\text { Journal of Agriculture - Food Science } \\
\text { and Technology (TURJAF 2021) } \\
\text { Gazimağusa/Cyprus }\end{array}$ & $\begin{array}{l}\text { The genus Helichrysum contains many species displaying therapeutical effects and use in folk } \\
\text { medicine. Helichrysum pallasii (Spreng.) Ledeb. is one of these species, used in the region for } \\
\text { traditional medicine and ornamental purposes. Plants have been used in the treatment in folk } \\
\text { medicines since the earliest times of human history. Chemical composition, antimicrobial and other } \\
\text { medicinal properties of plants are being investigated in laboratories throughout the world using the } \\
\text { extracts and essential oils derived from medicinal plants. Essential oils are usually complex mixtures } \\
\text { of natural compounds of both polar and apolar structure. Essential oils consist mainly of terpenoids } \\
\text { and their oxygenated derivatives. Essential oils, which have antioxidant and antimicrobial activities, } \\
\text { have therapeutic properties and are the raw materials of cosmetics, as well as acting as natural } \\
\text { additives in foods and food products. In this study, the volatile components of the } H \text {. pallasii plants } \\
\text { were investigated which collected from its natural habitat in the Armutlu district of Bayburt province } \\
\text { (Turkey) at the time of flowering. The proportion of essential oils of the plant harvested during the } \\
\text { full flowering period and the aromatic components in the essential oil of the plant were determined } \\
\text { using the SPME (Solid Phase Microextraction) method in a Gas Chromatography (GC-MS) device. } \\
\text { Almost } 37 \text { different components were found as a result of the analysis. The main components were } \\
\text { found as } \alpha \text {-Springene ( } 34.89 \% \text { ), (-)-Isoledene ( } 7.11 \% \text { ), } \delta \text {-Selinene (5.79\%) and Aristolene (5.09). }\end{array}$ \\
\hline
\end{tabular}

\section{Introduction}

Over the centuries, humankind rely on medicinal plants as a source of pharmaceuticals, flavours, agrochemicals, biopesticides, fragrances, colours and food additives (Balandrin and Klocke, 1988; Phillipson, 1990). Nevertheless, importance of medical plants is on the rise in parallel with international medicinal plants trade (Rao and Ravishankar, 2002). In commercial scale of plant products, seconder metabolites are prominent. Seconder metabolites could be categorized into three main categories; essential oils, glycosides and alkaloids. The essential oils are composed of combination of terpenoids, that are utilized mainly as solvents, flavoring agents and perfumes (Shuler, 1981). The genus Helichrysum Miller includes 500 species, belonging to the family of Asteraceae, spread around the world, represented in Turkish flora by 27 taxa in which 15 of them are endemic, comes into prominence as a significant source of secondary metabolites, mostly stands out for its' essential oil components. (Davis, 1975; Davis et al., 1988; Lawrence, 1998; Guner et al., 2000; Sumbul et al., 2003; Angioni et al., 2003; Appendino et al., 2007). The plants are generally utilized in traditional medicine preferred as a herbal tea for several biological effects such as antioxidant (Czinner et al., 2001; Tepe et al., 2005) antimicrobial activity (Sagdic et al., 2003) and antiinflammatory (Sala et al., 2003) in Turkey and other parts of the world. Helichyrsum pallasii (Spreng.) Ledeb. is distributed on steppe and rocky slopes at altitude of 1700$3600 \mathrm{~m}$ (Davis and Kupicha, 1975). Also, it was reported that $H$. pallasii displays antifungal, antiviral and antibacterial effects (Aslan et al., 2006). The genus Helichrysum is a unique source of a wide spectrum of secondary metabolites (Powell et al., 1965; Manitto et al., 1972; Lawrence, 1998; Appendino et al., 2007) and many of the species have been analyzed to reveal their essential oil contents. According to the studies, glandular trichomes positioned on the flower petals, sepals, bracts and also on the stem leaves are parts of the plant in which essential oils are produced. (Charles and Simon, 1991; Roussis et al., 2000; Bianchini et al., 2001; Angioni et al., 2003; Paolini et al., 2006). In this study, the essential oil components of the $H$. pallasii flowers were investigated which collected from its natural habitat in Armutlu district of Bayburt province (Turkey) at the time of flowering. 


\section{Materials and Methods}

This experiment was conducted at Field Crops Department, Faculty of Agriculture, Recep Tayyip Erdoğan University in 2021. H. pallasii was collected from its natural habitat in Armutlu district of Bayburt province, Turkey (Figure 1.).

The flower parts of $H$. pallasii (Figure 1) collected at the flowering time were used as plant material. Essential oil components were determined using a Shimadzu model GC-MS (2010 Plus) present in Plant Analysis Laboratory, Recep Tayyip Erdogan University, Faculty of Agriculture. SPME (Solid Phase Microextraction) method was used to determine essential oil components according to Yurteri et al. (2021).

\section{Results and Discussion}

Almost 37 different components were found as a result of the analysis. The main components were found as $\alpha$ Springene $(34.89 \%)$, (-)-Isoledene $(7.11 \%), \delta$-Selinene (5.79\%), Aristolen (5.09\%), $\beta$-Caryophy (4.76\%) and $\alpha$ Patchoulene (4.74\%) (Figure 1.). There are few studies related to essential oil components of $H$. pallasii. This study is the first report regarding the essential oil components investigating flowers of $H$. pallasii collected from Turkey.

Our results were different compared with a study conducted by Formisano et al.(2009). The researchers revealed that the main constituent of the oil from flowers of $H$. pallasii were 2592exadecenoic acid (14.7\%), (Z,Z)9,12-octadecadienoic acid (14.2\%), (Z)-caryophyllene (3.6\%), and delta-cadinene $(3.1 \%)$.

The main chemical groups of investigated essential oils were found as sesquiterpene hydrocarbons (48\%), diterpene hydrocarbons $(34.89 \%)$ and ethers, carboxylic acids and esters (11\%).

Chalchat and Özcan (2006), reported that main essential oil composition of $H$. pallasii were $\beta$ Caryophyllene (27.6\%), $\beta$-Selinene (8.9\%), $\alpha$-selinene $(8.4 \%)$, Caryophyllene oxide $(7.3 \%)$, and Carvacrol $(2.4 \%)$. The essential oil was almost totally characterized by sesquiterpene hydrocarbons such as $\beta$-Caryophyllene and $\alpha$ - and $\beta$-Selinene. Our results are in agreement with Chalchat and Özcan (2006)'s study with regard to $\beta$ Caryophyllene and Seline contents.

The current results revealed that volatile organic compounds of this Helychrisum species grown in Bayburt contains relatively different components when compared with the results of the same species grown in different places of the World (Formisano et al., 2009).

The variety and amount of bioactive substances present in medicinal and aromatic plants differ according to the part of the plant used, post-harvest processes, and the methods of obtaining and analyzing the essential oil used (Kaytanloglu et al., 2021). Essential oil components differ also according to environmental factors. Therefore more studies should be carried out on different types of Helichrysum species from different locations in Turkey, in gold grass species, in order to determine the chemical profiles of present Helichrysum spp. Species.
Table 1. Classification of detected essential oil components by terpene groups of $H$. pallasii

\begin{tabular}{|c|c|c|}
\hline Chemical Components & $\mathrm{KI}^{\mathrm{a}}$ & $\mathrm{EC}$ \\
\hline \multicolumn{3}{|c|}{ Monoterpene Hydrocarbons } \\
\hline$\alpha$-Pinene & 931 & 0.49 \\
\hline \multicolumn{3}{|c|}{ Monoterpene Oxygenes } \\
\hline 1,8-Cineole & 1030 & 0.8 \\
\hline \multicolumn{3}{|c|}{ Sesquiterpene Hydrocarbons } \\
\hline$\alpha$-Guaiene & 1346 & 0.39 \\
\hline$\alpha$-Ylangene & 1374 & 0.93 \\
\hline Cadinene & 1383 & 3.69 \\
\hline$\delta$-Guaiene & 1410 & 0.76 \\
\hline Trans(,Beta,)-Caryophy & 1423 & 4.76 \\
\hline Alloaromadendrene & 1442 & 2.78 \\
\hline Aristolene & 1446 & 5.09 \\
\hline (-)-Isoledene & 1455 & 7.11 \\
\hline$\alpha$-Humulene & 1457 & 1.53 \\
\hline$\alpha$-Patchoulene & 1482 & 4.74 \\
\hline$\delta$-Selinene & 1495 & 5.79 \\
\hline Zingiberene & 1497 & 1.1 \\
\hline$\beta$-Selinene & 1490 & 2.05 \\
\hline Naphthalene, 1,2,3,4,4a,5,6,8a-o & 1527 & 1.04 \\
\hline Valencene & 1540 & 0.65 \\
\hline$\beta$-Maaliene & 1568 & 1.08 \\
\hline$\alpha$-Amorphene & 1597 & 0.34 \\
\hline$\beta$-Guaiene & 1630 & 2.12 \\
\hline $6,10,11,11$-Tetramethyl-T & 1637 & 0.63 \\
\hline Cycloheptan, 4-Methyl & 1656 & 0.7 \\
\hline$\alpha$-Calacorene & 1547 & 1.16 \\
\hline \multicolumn{3}{|c|}{ Diterpene Hydrocarbons } \\
\hline$\alpha$-Springene & 1915 & 34.89 \\
\hline \multicolumn{3}{|l|}{ Others } \\
\hline Linalool & 1099 & 1.08 \\
\hline Spathulenol & 1901 & 0.33 \\
\hline Tricyclo[3,2,1,0(2,7)]oct-3-ene, & 1390 & 2.63 \\
\hline Linalyl acetate & 1256 & 0.41 \\
\hline
\end{tabular}

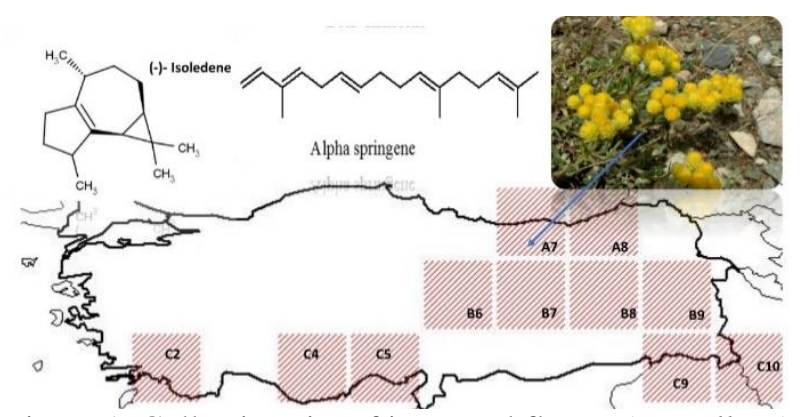

Figure 1. Collection site of immortal flower (H. pallasii) (Armutlu district of Bayburt province, Turkey)(TUBIVES Grids).

ESSENTIAL OIL COMPONENTS (\%)

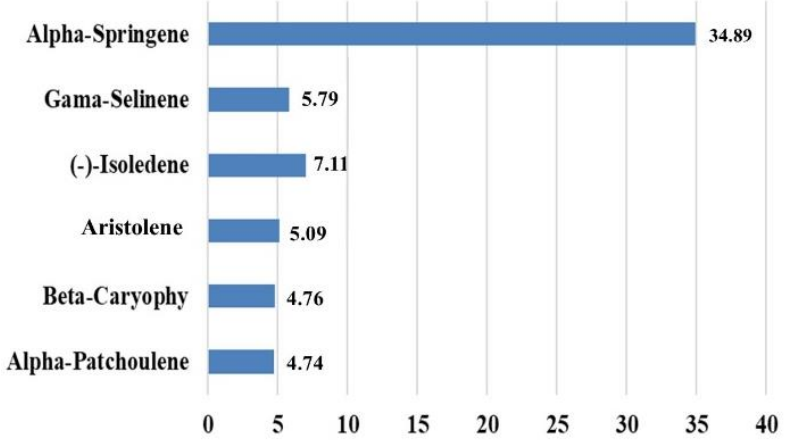

Figure 2. Main essential oil components of $H$. pallasii 


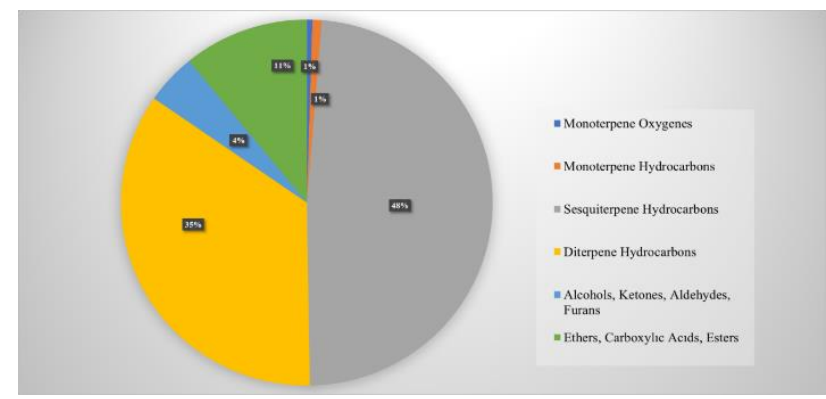

Figure 3. Terpene groups of detected essential oil components of $H$. pallasii

\section{References}

Angioni A, Barra A, Arlorio M, Coisson D, Russo T, Pirisi M, Satta M, Cabras P. 2003. Chemical composition, plantgenetic differences, and antifungal activity of the essential oil of Helichrysum italicum G. Don ssp. michrophyllum (Willd) Nym. Journal of Agricultural and Food Chemistry, 51:10301034. Doi: $10.1021 / \mathrm{jf025940c.}$

Appendino G, Ottino M, Marquez N, Bianchi F, Giana A, Ballero M, Sterner O, Fiebich BL, Munoz E. 2007. Arzanol, an antiinflammatory and anti-HIV-1 phloroglucinol $\alpha$-pyrone from Helichrysum italicum ssp. microphyllum. Journal of Natural Products, 70, 608-612. Doi: 10.1021/np060581r.

Aslan M, Özçelik B, Orhan I, Karaoglu T, Sezik E. 2006. Screening of antibacterial, antifungal and antiviral properties of the selected Turkish Helichrysum species. Planta Medica, 72: 997-997. DOI:10.1055/s-2006-949845

Balandrin MJ, Klocke JA. 1988. Medicinal, aromatic and industrial materials from plants. In: Bajaj YPJ, editor. Biotechnology in agriculture and forestry. Medicinal and Aromatic Plant, vol. 4. Berlin: Springer-Verlag, pp. 1-36.

Bianchini A, Tomi P, Costa J, Bernardini AF, 2001. Composition of Helichrysum italicum G. Don fil. Subsp. italicum essential oils from Corsica (France). Flavour and Fragrance Journal, $16,30-34$.

Chalchat JC, Özcan MM. 2006. Composition of the essential oil of Helichrysum chasmolycicum growing wild in Turkey. Journal of Medicinal Food, 9(2), 287-289. DOI:10.1089/jmf.2006.9.287.

Charles DJ, Simon JE, 1991. Volatile compounds of the curry plant. Horticultural Science, 26, 69-70.

Czinner E, Lemberkovics É, Bihátsi-Karsai E, Vitányi G, Lelik L. 2000. Composition of the essential oil from the inflorescence of Helichrysum arenarium (L.) Moench. Journal of Essential Oil Research, 12(6), 728-730.

Davis PH, Kupicha FK. 1975. Helichrysum Gaertn. In: Davis PH. Ed. Flora of Turkey and the East Aegean Islands vol 5. Edinburgh University Press, Edinburgh; pp. 80-97.

Davis PH. (Ed.). 1975. Flora of Turkey and the East Aegean Islands (Vol. 5, pp. 80-97). Edinburgh, UK: Edinburgh University Press.
Davis PH, Mill RR, Tan K. (Eds.). 1988. Flora of Turkey and the East Aegean Islands (Vol. 10, pp. 159-160). Edinburgh, UK: Edinburgh University Press.

Formisano C, Mignola E, Rigano D, Senatore F, Arnold NA, Bruno M, Rosselli S. 2009. Constituents of leaves and flowers essential oils of Helichrysum pallasii (Spreng.) Ledeb. Growing wild in Lebanon. Journal of Medicinal Food, 12(1), 203-207. Doi: 10.1089/jmf.2008.0103.

Guner A, Ozhatay N, Ekim T, Baser KHC (Eds.). 2000. Flora of Turkey and the East Aegean Islands (Vol. 11, pp. 153-154). Edinburgh, UK: Edinburgh University Press.

Kaytanlığlu EHT, Özderin S, Fakir H, Gümüşay E. 2021. Determination of Volatile Components of Helichrysum arenarium subsp. aucheri Naturally Distributed in Two Different Regions. European Journal of Science and Technology, 25, 152-158.

Lawrence BM. 1998. Helichrysum oil and extract. Perf. Flavor, $23,55-59$.

Shuler ML. 1981. Production of secondary metabolites from plant tissue culture-problems and prospects. Annals of the New York Academy of Sciences, 369 65-79.

Manitto P, Monti D, Colombo E, 1972. Two new B-diketones from Helichrysum italicum. Phytochemistry, 11, 2112-2114.

Paolini J, Desjober JM, Costa J, Bernardini AF, Buti Castellini C, Cioni PL, Flamini G, Morelli I. 2006. Composition of essential oils of Helichrysum italicum G. Don fil. Subsp. italicum from Tuscan Achipelago islands. Flavour and Fragrance Journal, 21, 805-808. https://doi.org/10.1002/ffj.1726

Phillipson JD. 1990. Plants as source of valuable products. In: Charlwood BV, Rhodes MJC, editors. Secondary products from plant tissue culture. Oxford: Clarendon Press, pp. 1-21.

Powell RG, Smith Jr, CR, Glass CA, Wolff IA. 1965. Helichrysum seed oil. II. Structure and chemistry of a new enynolic acid. The Journal of Organic Chemistry, 30, 610615.

Rao SR, Ravishankar GA. 2002. Plant cell cultures: Chemical factories of secondary metabolites. Biotechnology Advances, 20 (2002) 101-153.

Roussis V, Tsoukatou M, Petrakis PV, Chinou I, Skoula M, Harborne JB. 2000. Volatile constituents of four Helichrysum species in Greece. Biochemical Systematics and Ecology, 28, 163-175.

Sala A, Recio MC, Schinella GR, Màñez S, Giner RM et al. 2003. Assessment of the antiinflammatory activity and free radical scavenger activity of tiliroside. European Journal of Pharmacology, 461: 53-61.

Sumbul H, Gokturk RS, Dusen, OD. 2003. A new endemic species of Helichrysum Gaertn. (Asteraceae-Inuleae) from south Anatolia. Botanical Journal of the Linnean Society, $141,251-254$

Tepe B, Sokmen M, Akpulat HA, Sokmen A. 2005. In vitro antioxidant activities of the methanol extracts of four Helichrysum species from Turkey. Food Chemistry, 90(4), 685-689. DOI:10.1016/j.foodchem.2004.04.030.

Yurteri E, Makbul S, Coskuncelebi C, Seyis F. 2021. Essential Oil Composition In Different Plant Parts of Scorzonera acuminata. New Developments in Medicinal and Aromatic Plants (Ed. Gülen Özyazici), 243-263. 